\title{
Accelerated bacterial inactivation obtained by HIPIMS sputtering on low cost surfaces with concomitant reduction in the metal/semiconductor content ${ }^{\dagger}$
}

Received 28th March 2013,

Accepted 10th June 2013

DOI: $10.1039 / \mathrm{c} 3 \mathrm{ra} 41528 \mathrm{~g}$

www.rsc.org/advances

Novel ultrathin $\mathrm{TiO}_{2}-\mathrm{Cu}$ nanoparticulate films sputtered by highly ionized pulsed plasma magnetron sputtering (HIPIMS) lead to faster bacterial inactivation compared to more traditional sputtering approaches with an appreciable metal saving. HIPIMS sputtering induces a strong interaction of the $\mathrm{TiO}_{2}-\mathrm{Cu}$-ions $\left(\mathrm{M}^{+}\right)$ with the polyester surface due to the high fraction and density of $\mathrm{M}^{+}$-ions interacting with the biased substrate.

Antimicrobial surfaces can reduce/eliminate hospital-acquired infections (HAI) acquired on contact with bacteria surviving for long times in hospital facilities. ${ }^{1,2}$ To preclude/decrease viral, nosocomial infections and antibiotic resistant bacteria Borkow and $\mathrm{Gabbay}^{3}$ introduced $\mathrm{Cu}$ into textile fabrics. Recently Sunada et al., ${ }^{4,5}$ and Irie et $a l^{6}$ have reported the preparation of the $\mathrm{Cu}$ and $\mathrm{TiO}_{2}-\mathrm{Cu}$ films by sol-gel methods and with absorption in the visible range. The sol-gel deposited films are not mechanically stable, in many cases their preparation is not reproducible and do not present uniformity but only low adhesion since they can be wiped off by a cloth or thumb. ${ }^{7}$ Films obtained by direct current magnetron sputtering (DC/DCP) as reported avoid the disadvantages of Cu-films prepared by sol-gel methods ${ }^{4-7}$ since they deposit uniform and adhesive metal films chemical bonding and mechanical interlocking leading on substrates resisting up to 120 $130{ }^{\circ} \mathrm{C}$.

In recent years physical vapour deposition (PVD) has been used to produce antimicrobial films by condensation of a vaporized precursor onto the substrate at relatively high temperatures. Parkin, ${ }^{8}$ Foster $^{9}$ and Dunlop ${ }^{10}$ have reported antibacterial film preparation of $\mathrm{Ag}$ and $\mathrm{Cu}$ films on glass and thin polymer films by PVD. $\mathrm{TiO}_{2}, \mathrm{Ag}$, and $\mathrm{Cu}$ films 6 to $50 \mathrm{~nm}$ thick have been shown to inactivate bacteria under UV and in some cases under visible light irradiation. The disadvantages of the PVD deposition approach are the high investment costs, the high temperatures needed precluding film deposition on textiles besides the large amount

${ }^{a}$ Ecole Polytechnique Fédérale de Lausanne, EPFL-SB-ISIC-GPAO, Station 6, CH1015, Lausanne, Switzerland

${ }^{b}$ Ecole Polytechnique Fédérale de Lausanne, EPFL-SB-ISIC-LPI, Bat Chimie, Station 6, CH1015, Lausanne, Switzerland

† Electronic supplementary information (ESI) available. See DOI: 10.1039/c3ra41528g of heat used requiring costly cooling systems. Highly ionized pulsed plasma magnetron sputtering (HIPIMS) has been reported recently able to sputter films applying strong electrical pulses leading to layers presenting superior resistance against corrosion and oxidation. ${ }^{11}$ The non-uniform deposition on rugous and complex shape substrates is one of the main problems encountered when depositing uniform Cu-films by direct current pulsed magnetron sputtering (DC/DCP). ${ }^{12} \mathrm{Cu}$-polyester has been shown to be effective against Gram-positive $S$. Aureus as reported recently. ${ }^{13}$ This study addresses HIPIMS sputtering on polyester leading to ultrathin uniform films showing an accelerated bacterial deactivation due to the induced high energy $\mathrm{Cu}$-ions $\left(\mathrm{M}^{+}\right)$produced in the magnetron chamber, the HIPIMS plasma density and the increased effect of the applied bias voltage on the Cu-ions $\left(\mathrm{M}^{+}\right)$compared to DC/DCP sputtering.

HIPIMS deposition of $\mathrm{Cu}$ was carried out in a CMS-18 Vacuum system from Kurt Lesker Ltd. using $\mathrm{Cu}$ and $\mathrm{TiO}_{2}$ targets of $50 \mathrm{~mm}$ in diameter (K. Lesker Ltd. UK). The $\mathrm{TiO}_{2}-\mathrm{Cu}$ composite target had composition of 60/40 atomic\% in $\mathrm{TiO}_{2}-\mathrm{Cu}$. The HIPIMS was operated at $500 \mathrm{~Hz}$ with pulses of $100 \mathrm{~ms}$ separated by $1.9 \mathrm{~ms}$, leading to a deposition rate for $\mathrm{TiO}_{2}-\mathrm{Cu}$ of $15.3 \mathrm{~nm} \mathrm{~min}{ }^{-1}$. The average power was $87.5 \mathrm{~W}(5 \mathrm{~A} \times 350 \mathrm{~V})$ and the power per pulse of $100 \mathrm{~ms}$ was $1750 \mathrm{~W}$. In the case of DCP, $622 \mathrm{~V}$ and $0.3 \mathrm{~A}$ were applied during 3 pulses of $10 \mathrm{~ms}$ each, within a $50 \mathrm{~ms}$ period. This gives $187 \mathrm{~W}$ per period or $62.3 \mathrm{~W}$ per pulse and an average power of $312 \mathrm{~W}$ per sputtering cycles. The polyester-Dacron terephthalate EMPA test cloth no. 407. 54 spun, 130 microns thick is known for his high mechanical and chemical resistance. Fibers were made of particle sizes $<500 \mathrm{~nm}$ and present a tensile strength of $75 \mathrm{MPa}$, refractive index 1.57 an density $1.38 \mathrm{~g} \mathrm{~cm}^{-3}$ with a melting point of $250{ }^{\circ} \mathrm{C}$. The 3 -D term used to describe the 130 microns thick polyesters fabric addresses the wide misconception that these fabrics are flat and uniform which is not the case, since it is made of fibers 0.3 to 0.5 micron thick. The film thickness was determined with a profilometer (Alphastep500, TENCOR). The $\mathrm{X}$-ray fluorescence (XRF) determination of the Ti-Cu samples was evaluated in a PANalytical PW2400 spectrometer. The Esherichia coli $\left(E\right.$. coli) counting was evaluated according to references ${ }^{13-15}$ and the experimental points replicated three times. The statistical 
analysis of the results was performed for the decrease of the bacterial CFU values reporting the standard deviation values for the runs showing the fastest bacterial inactivation. Irradiation of the samples was carried out in the cavity of an Osram Lumilux 18

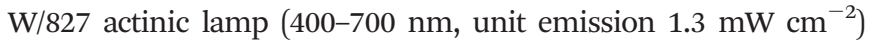
being $30 \mathrm{~cm}$ the distance between the light source and the sample. Transmission electron microscopy (TEM) was carried out in a Philips CM-12 microscope at $120 \mathrm{kV}$. X-ray Photoelectron Spectroscopy (XPS) used an AXIS NOVA photoelectron spectrometer (Kratos Analytical, Manchester, UK) and the surface atomic concentration of the elements was determined using known sensitivity factors. ${ }^{16}$

Thickness calibrations were carried out for HIPIMS sputtered films on Si-wafers at $5 \mathrm{~A}$ from a target $\mathrm{TiO}_{2}-\mathrm{Cu} 60 \% / 40 \%$ for $150 \mathrm{~s}$ leading to the faster bacterial inactivation. The composite film was $38 \mathrm{~nm}$ thick for $\mathrm{TiO}_{2}-\mathrm{Cu}$ sputtered for $150 \mathrm{~s}$. This is equivalent to $\sim 190$ layers 0.2 thick $\mathrm{nm}$ with $10^{15}$ atoms $\mathrm{cm}^{-2}$ per layer deposited at a rate of $7.6 \times 10^{16}$ atoms $/ \mathrm{cm}^{2} \mathrm{~min}^{-1}$. X-ray fluorescence (XRF) indicated a composition $0.29 \%$ wt $\mathrm{CuO}$ and a $0.45 \%$ wt $\mathrm{TiO}_{2}$ per weight polyester.

Under actinic light, Fig. 1a, traces 3, 4 and 5 show the bacterial inactivation as the sputtering time was increased up to $150 \mathrm{~s}$. Sputtering for $300 \mathrm{~s}$ induces bacterial inactivation taking longer times than the sample sputtered for $150 \mathrm{~s}$. Therefore, the amount of $\mathrm{Cu}^{0}$ is not the main species leading to bacterial inactivation. This sample presents the highest amount of $\mathrm{Cu}$-sites held in exposed positions interacting on the surface or close to the polyester surface with $E$. coli and leading to bacterial inactivation. ${ }^{12,13} \mathrm{~A}$ very high dispersion is attained by sputtering $\mathrm{CuO}$ on $\mathrm{TiO}_{2}$. The visible light is absorbed by $\mathrm{CuO}$. We suggest that no $\mathrm{e}^{-}$ injection is possible from the CuOcb (at $-0.30 \mathrm{eV} v \mathrm{~s}$. SCE at pH 7) to the $\mathrm{TiO}_{2} \mathrm{cb}(-0.60 \mathrm{eV}$ vs. SCE, $\mathrm{pH} 7)$. Also the CuOvb $(+1.4 \mathrm{eV})$ cannot transfer the $\mathrm{CuO}$ holes to the $\mathrm{TiO}_{2} \mathrm{vb}$ at $2.5 \mathrm{eV}$. These energetic considerations lead us to rationalize the fast kinetics reported in Fig. 1a as due to the high $\mathrm{CuO}$ dispersion on $\mathrm{TiO}_{2}$.

Diffuse reflectance spectroscopy (DRS) show that the absorption in Kubelka-Munk units of the $\mathrm{Cu}$ absorption lies between 250 and $650 \mathrm{~nm}$ and increases with longer Cu-sputtering times. ${ }^{14}$ The DRS intensity was directly related with the bacterial inactivation kinetics times under light irradiation (see Fig. 1a). The Cu-particles present sizes between 8-12 nm. The distribution of $\mathrm{TiO}_{2}$ and $\mathrm{Cu}-$ nanoparticles was found to be uniform without cracks. The charge transfer between the $\mathrm{TiO}_{2} / \mathrm{Cu}$ sample and the $E$. coli depends on the diffusion of the charges on the $\mathrm{TiO}_{2}-\mathrm{Cu}$ and this is a function of the particle size. ${ }^{4,14}$ Due to its size, the $\mathrm{CuO}-\mathrm{Cu}$ nanoparticles are not able to penetrate the bacteria cell wall porins with a diameter of 1.1-1.5 nm, ${ }^{13-15}$ but Cu-ions are able to diffuse through bacterial porins leading to DNA damage and finally to bacterial inactivation. ${ }^{2,13}$ More pathogenic thick walled bacteria like Staphylococcus aureus with cell wall $\sim 40 \mathrm{~nm}$ have been recently reported to be inactivated by $\mathrm{Cu}$-polyester in the dark. ${ }^{13}$ Repetitive recycling of the $\mathrm{TiO}_{2}-\mathrm{Cu}(150 \mathrm{~s})$ samples up to the 8th cycle showed no loss in activity suggesting a stable content of CuO-Cu-ions in the $\mathrm{TiO}_{2}$ film.

Fig. 2 presents the inactivation time $v s$. thickness for DCP and HIPIMS $\mathrm{TiO}_{2}-\mathrm{Cu}$ sputtered films. Fig. 2 also shows the significant
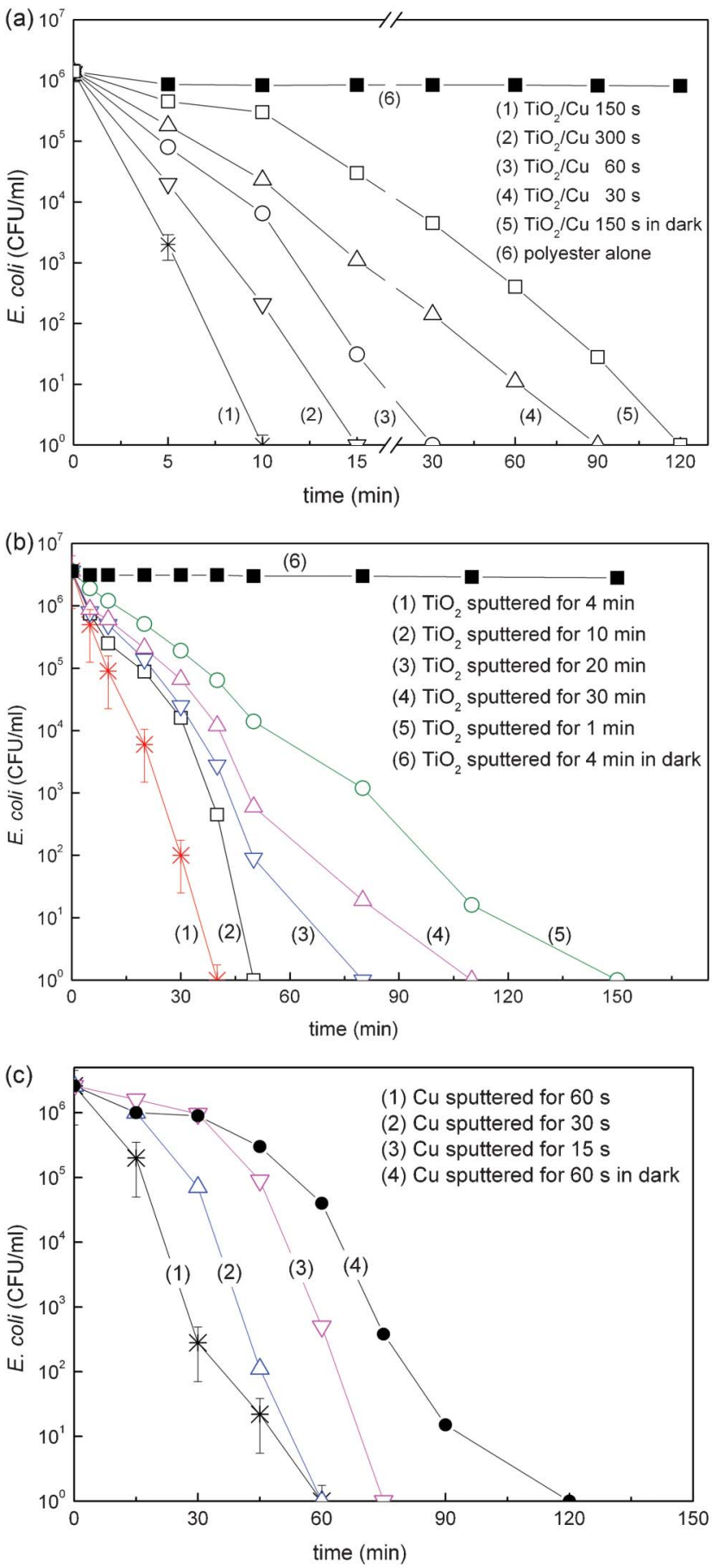

Fig. 1 (a) E. coli survival on $\mathrm{TiO}_{2}-\mathrm{Cu}$ polyester samples under Osram Lumilux $18 \mathrm{~W} /$ 827 actinic lamp irradiation $\left(4.2 \mathrm{~mW} \mathrm{~cm}^{-2}\right.$ ). (b) E. coli survival on $\mathrm{TiO}_{2}$ HIPIMSsputtered on polyester samples for different times in the dark and under Osram Lumilux $18 \mathrm{~W} / 827$ actinic lamp $\left(4.2 \mathrm{~mW} \mathrm{~cm}{ }^{-2}\right)$. (c) E. coli survival on Cu HIPIMSsputtered samples for different times in the dark and under Osram Lumilux $18 \mathrm{~W} /$ 827 light $\left(4.2 \mathrm{~mW} \mathrm{~cm}^{-2}\right)$.

reduction for the HIPIMS $\mathrm{TiO}_{2}-\mathrm{Cu}$ layer thickness compared to DC/DCP deposited layer thickness required to inactivate bacteria. The HIPIMS film with a thickness of $38 \mathrm{~nm}$ required $\sim 10 \mathrm{~min}$ to inactivate bacteria compared with a thickness layer of $600 \mathrm{~nm}$ 


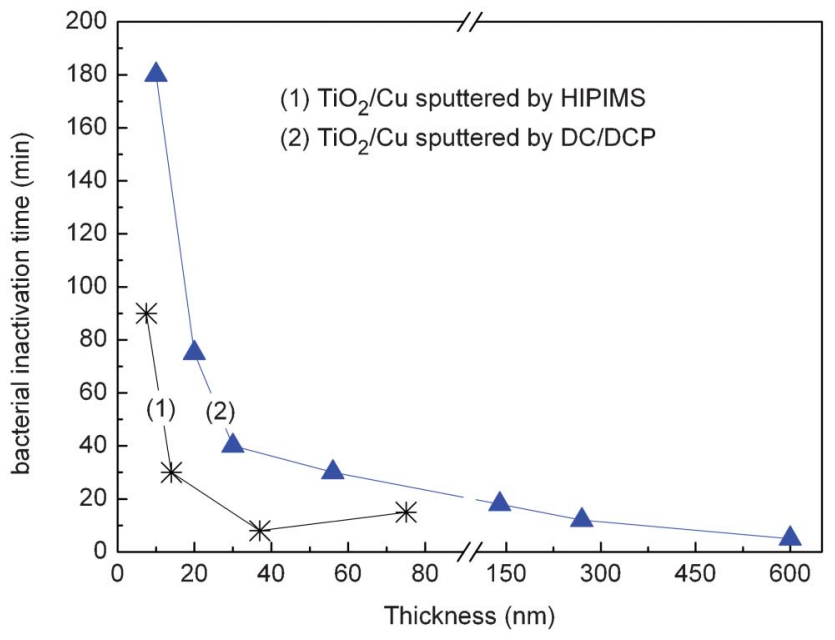

Fig. 2 Bacterial inactivation time vs. nominal thicknesses for HIPIMS sputtered $\mathrm{TiO}_{2}-$ Cu films and DC/DCP sputtered films.

when applying DC/DCP sputtering. To explain the result shown in Fig. 2 the HIPIMS power per pulse was $1750 \mathrm{~W} / 100 \mu \mathrm{s}$. This value is significantly higher than the power per pulse applied by DCP of 62.3 W/10 $\mu \mathrm{s}$. The HIPIMS charge density is two orders of magnitude higher than in DCP and comprising pulses $\sim 60$ times more energetic than the pulses applied by DCP.

The thinner films deposited by HIPIMS in Fig. 2 show that fast bacterial inactivation kinetics are possible due to the HIPIMS energy increasing the ionization percentage $\mathbf{M} \rightarrow \mathbf{M}^{+}$and leading to the alignment of the $\mathrm{M}^{+}$-ions on the polyester surface. ${ }^{18,19}$ The HIPIMS proceeds with a $\mathrm{M}^{+}$ionization level of $\sim 70 \%$ and an electronic density of $\sim 10^{18-19} \mathrm{e}^{-} \mathrm{m}^{-3}$ compared to DCPsputtering with an ionization of $\mathrm{M}^{+}>5 \%$ and an electronic density $\sim 10^{15-16} \mathrm{e}^{-} \mathrm{m}^{-3} \cdot{ }^{11,17}$ The $\mathrm{M}^{+}$-ions produced in the plasma are attracted to the biased substrate applied on the substrate

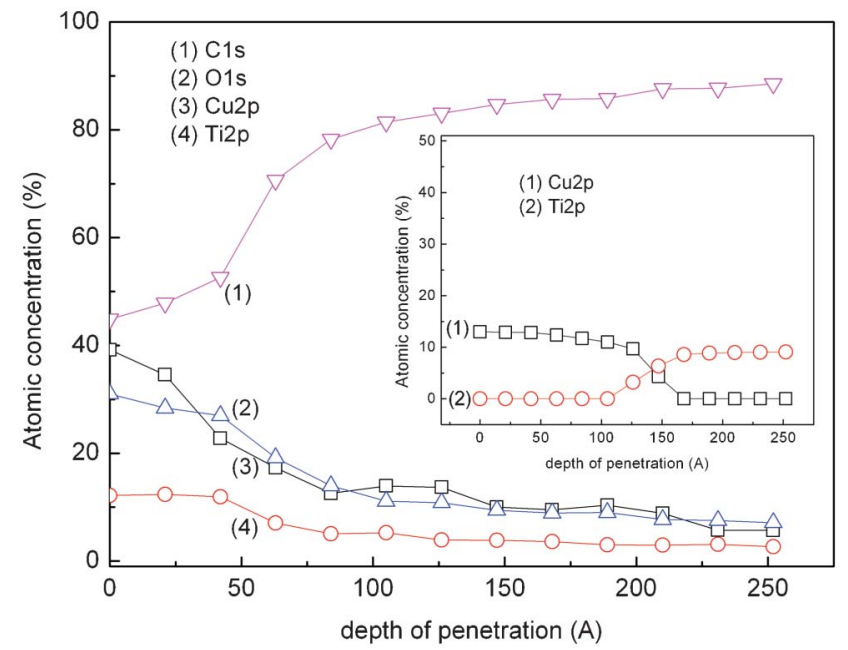

Fig. 3 XPS etching of $\mathrm{TiO}_{2}-\mathrm{Cu}$ HIPIMS sputtered on polyester showing the penetration of the elements up to 250 Angströms ( 120 atomic layers). Insert: depth profile of $\mathrm{TiO}_{2}-\mathrm{Cu}$ on polyester sputtered by DCP.
$(-200 \mathrm{~V})$. This results in a normal incidence of the $\mathrm{M}^{+}$-ions on the substrate surface re-directing the $\mathrm{M}^{+}$-ion deposition. ${ }^{19}$ The applied bias voltage has a more important effect when using HIPIMS sputtering compared to DCP, due to the high charge density generated by HIPIMS in the magnetron chamber.

Fig. 3 presents the atomic percentage concentration of $\mathrm{Cu}, \mathrm{Ti}$, $\mathrm{O}_{2}$ and $\mathrm{C}$ in the sample of $\mathrm{TiO}_{2}-\mathrm{Cu}$ sputtered for $150 \mathrm{~s}$ as a function of $\mathrm{Ar}^{+}$depth penetration. It is readily seen that the concentration of $\mathrm{Cu}, \mathrm{Ti}$ and $\mathrm{O}$ decrease up to $240 \AA$. The penetration of Ar-ions was referenced by the standard value of 15 atomic layers of Ta etched per minute $\left(\sim 30 \AA \min ^{-1}\right)$. The
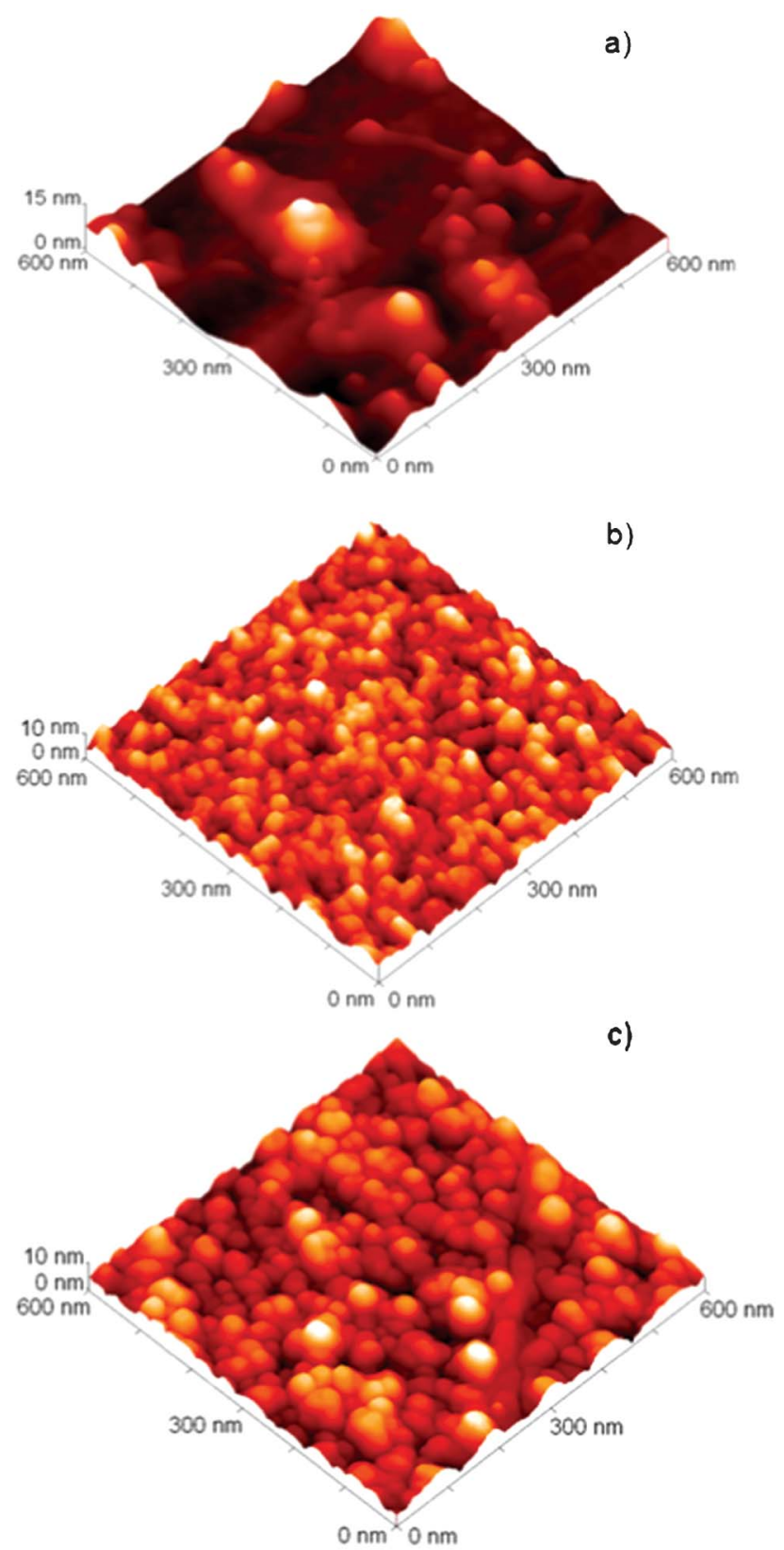

Fig. 4 Atomic force microscopy (AFM) of: (a) Cu sputtered with HIPIMS for $150 \mathrm{~s}$ ( $\mathrm{rms}=8.35 \mathrm{~nm}$ ), (b) $\mathrm{TiO}_{2}$ sputtered with HIPIMS for $4 \mathrm{~min}(\mathrm{rms}=3.15 \mathrm{~nm}$ ) and (c) $\mathrm{TiO}_{2}-\mathrm{Cu}$ sputtered with HIPIMS for $30 \mathrm{~s}(\mathrm{rms}=5.6 \mathrm{~nm})$. 

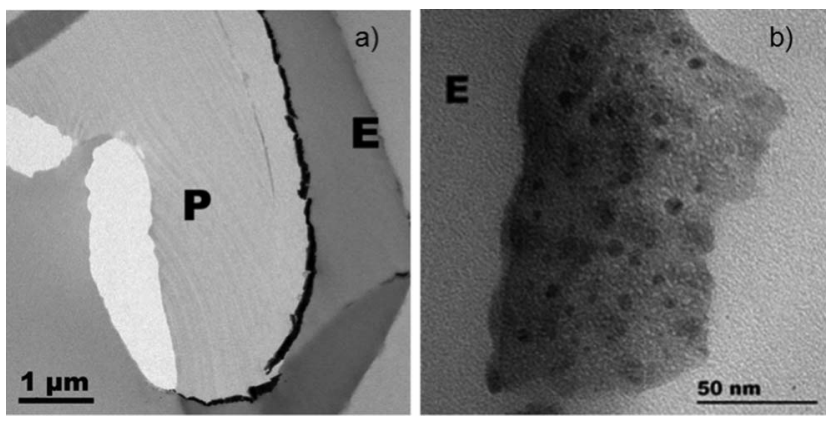

Fig. 5 Transmission electron microscopy (TEM) of: (a) $\mathrm{TiO}_{2}-\mathrm{Cu}$ HIPIMS sputtered for $150 \mathrm{~s}$ covers continuously the surface of the polyester fiber and (b) $\mathrm{TiO}_{2}-\mathrm{Cu}$ HIPIMS on polyester sputtered for $150 \mathrm{~s}$ showing the nanoparticle sizes 8-12 nm.

penetration of the $\mathrm{Cu}$ into the polyester protects the $\mathrm{Cu}$-clusters inside the $130 \mu \mathrm{m}$ thick polyester network during the E. coli inactivation process. The increase in the C-content in Fig. 3 was due to the etching removing the $\mathrm{TiO}_{2}-\mathrm{Cu}$ layers making available a larger fraction the C-content of the polyester. The insert in Fig. 3 shows the significantly lower atomic concentration percentage of $\mathrm{Cu}$ and $\mathrm{Ti}$ for $\mathrm{TiO}_{2}-\mathrm{Cu}$ sputtered by DC/DCP compared to HIPIMS sputtering. The results in Fig. 3 show the penetration in the polyester of $\mathrm{Cu}, \mathrm{Ti}, \mathrm{C}$ and $\mathrm{O}$ on the polyester samples etched by Arions as detected by XPS. The most interesting observation shown in Fig. 3 is the pattern of the Ti, $\mathrm{Cu}$ and $\mathrm{O}$ profiles when a target with a composition 60/40 atomic $\% \mathrm{TiO}_{2}-\mathrm{Cu}$ was used for the simultaneous sputtering of $\mathrm{Ti}$ and $\mathrm{Cu}$.

Recent studies reported the visible light-sensitive $\mathrm{TiO}_{2}-\mathrm{Cu}$ photocatalyst showing interfacial charge transfer (IFCT) leading to the electron transfer from $\mathrm{TiO}_{2} \mathrm{vb}$ to $\mathrm{Cu}(\mathrm{II}) .{ }^{6}$ In a second more extended study these authors reported the film antibacterial activity was due to $\mathrm{TiO}_{2}$ holes in the valence band and $\mathrm{Cu}(\mathrm{I})$ produced by IFCT in $\mathrm{Cu}$ nano-cluster. ${ }^{20}$ The interfacial charge transfer would proceed with a considerable driving force induced by the large gap between the $\mathrm{TiO}_{2} \mathrm{vb}$ and the $\mathrm{Cu}(\mathrm{II}) / \mathrm{CuOvb}$ leading to the fast $E$. coli inactivation times of $\sim 10$ min shown in Fig. 1a compared to the times noted for the bacterial degradation in Fig. 1b/1c.

Fig. 4 presents the rugosity of the $\mathrm{TiO}_{2}-\mathrm{Cu}, \mathrm{TiO}_{2}$ sputtered and $\mathrm{Cu}$ sputtered samples inducing the fastest bacterial inactivation. The rugosity of the surfaces are close to each other and are relatively low within the detection limit of the AFM instrument ( $<10$ microns).

The adhesion of the $\mathrm{TiO}_{2}-\mathrm{Cu}$ nanoparticles to a polyester fiber is shown in Fig. 5 by Transmission electron microscopy (TEM) for a $\mathrm{TiO}_{2}-\mathrm{Cu}$ HIPIMS sputtered sample for 150 s. Continuous coverage of the polyester fiber is seen in Fig. 5a. The $\mathrm{TiO}_{2}-\mathrm{Cu}$ nanoparticle sizes $8-12 \mathrm{~nm}$ is shown for this sample in Fig. $5 \mathrm{~b}$.

\section{Conclusions}

The first evidence is presented for the functionalization of polyester by very thin HIPIMS layers of $\mathrm{TiO}_{2}-\mathrm{Cu}$ along the kinetics and microstructure of these films leading to bacterial inactivation. The bacterial inactivation by the $\mathrm{TiO}_{2}-\mathrm{Cu}$ films was faster compared to $\mathrm{Cu}$ or $\mathrm{TiO}_{2}$ sputtered separately. Savings in metal and deposition time (energy) was attained with HIPIMS compared to conventional DC/DCP-sputtering.

\section{Acknowledgements}

We thank the COST Actions MP0804 and MP1106, the EPFL and LIMPID FEP-7 Collaborative European Project Nanocomposite Materials NMP 2012.2.2.2-6 (N. 310177) for support of this work. We also thank Dr R. Bandorf (Braunschweig, GE) for his help with the HIPIMS work.

\section{References}

$1 \mathrm{~K}$. Taylor, R. Roberts and J. Roberts, The challenge of hospital acquired infections (HAI), Nat. Audit Office, UK, 2002.

2 S. Dancer, J. Hosp. Infect., 2009, 73, 378-389.

3 G. Borkow and J. Gabbay, J. FASEB, 2004, 188, 1728-1730.

4 K. Sunada, T. Watanabe and K. Hashimoto, Environ. Sci. Technol., 2003, 37, 4785-4789.

5 H. Irie, S. Miura, K. Kamiya and K. Hashimoto, Chem. Phys. Lett., 2008, 457, 202-205.

6 H. Irie, K. Kamiya, T. Shibanuma, S. Miura, D. Tryk, T. Yokohama and K. Hashimoto, J. Phys. Chem. C, 2009, 113, 10761-10766.

7 L. Zhang, R. Dillert and D. Bahnemann, Energy Environ. Sci., 2012, 5, 7491-7507.

8 K. Page, M. Wilson and P. Parkin, J. Mater. Chem., 2009, 19, 3819-3831 and references therein.

9 H. A. Foster, D. W. Sheel, P. Sheel, P. Evans, S. Varghese, N. Rutschke and H. M. Yates, J. Photochem. Photobiol., A, 2010, 216, 283-289.

10 P. S. M. Dunlop, P. C. Sheeran, J. A. Byrne, M. A. S. McMahon, M. A. Boyle and K. G. McGuigan, J. Photochem. Photobiol., A, 2010, 216, 303-3010.

11 K. Sarakinos, J. Alami and D. Konstantinidis, Surf. Coat. Technol., 2010, 204, 1661-1684.

12 P. Osorio, R. Sanjines, C. Ruales, C. Castro, C. Pulgarin, J.A. Rengifo, J.-C. Lavanchy and J. Kiwi, J. Photochem. Photobiol., A, 2011, 220, 70-76.

13 A. Rio, E. Kusiak, J. Kiwi, C. Pulgarin, A. Trampuz and A. Bizzini, Appl. Environ. Microbiol., 2012, 78, 8176-8182.

14 O. Baghriche, S. Rtimi, C. Pulgarin, R. Sanjines and J. Kiwi, ACS Appl. Mater. Interfaces, 2012, 4, 5234-5240.

15 H. Nikaido, J. Biol. Chem., 1994, 4, 3905-3908.

16 D. Wagner(Ed), Handbook of X-ray Photoelectron Spectroscopy, Perkin-Elmer Corporation Physical Electronics Division, Minnesota, 1979.

17 P. Kelly and R. Arnell, Vacuum, 2000, 56, 159-172.

18 I. Petrov, L. Hultman, U. Helmersson and J. Sundgren, Thin Solid Films, 1989, 169, 299-314.

19 V. Kousznetsov, K. Macak, J. Schneider, U. Helmersson and I. Petrov, Surf. Coat. Technol., 1999, 122, 290-295.

20 X. Qiu, K. Sunada, M. Minoshima, M. Liu, Y. Lu, D. Li, Y. Shimodaira, Y. Hosogi, Y. Kuroda and K. Hashimoto, ACS Nano, 2012, 6, 1609-1618. 